\title{
Intergenerational transmission of political participation intention
}

\author{
Ellen Quintelier
}

Article accepted for publication in Acta Politica

\begin{abstract}
Political participation is a prerequisite for democracy. Therefore, political sociologists have advised to socialize people by encouraging political participation from a young age onwards. Parents are one of the most important political socialization agents, especially at a young age. Although the intergenerational transmission of political attitudes has been studied quite intensively, the transmission of the political participation intention has been neglected. This study explores the effect of both mothers' and fathers' political activity on their offspring's intention to participate. Using a dataset from 2,085 Belgian parent-child triads (PCSS 2012), we tested the direct and indirect transmission of political participation intention. We found that although there is a direct transmission of political participation intention, after controlling for political discussion, political interest and socio-economic status, this effect is completely mediated. Therefore, we conclude that intergenerational transmission is an indirect process, supported by a high socio-economic status, more political interest and a more politicized family environment in which politics is clearly perceived as salient.
\end{abstract}

\section{KEY WORDS}

- Parent - child relations

- Intergenerational transmission

- Political participation 
- Political attitudes

- Structural equation modeling

\section{INTRODUCTION}

This article explores the intergenerational transmission of political participation intention from parents to children. Intergenerational transmission is defined as "the transfer of individual abilities, traits, behaviors, and outcomes from parents to their children" (Lochner, 2008), in this case political participation. The family is often considered the primary socialization context for young people with regard to political attitudes and behaviors. In general, young children tend to have their first political discussions or experiences with their parents. In the classic literature on political socialization, the family was regarded as the most important determinant of young people's attitudes and behaviors (Hyman, 1959, Davies, 1965, Langton, 1969, Dawson and Prewitt, 1969, Bronfenbrenner, 1979). Within the family, young people learn to fulfill social, gender and political roles, and how to interact with the larger community. Parents today still play a central role in developing young people's political participation intention, yet it is unclear whether this process happens directly (i.e., the parents' political participation directly influences the children's political participation intention) and/or indirectly (i.e., the effect of the parents' political participation is mediated by several factors) (Gordon, 2008, Quéniart, 2008, Matthews et al., 2010, Nesbit, 2012).

The intergenerational transmission of political attitudes (i.e., political interest, political efficacy and ideological preferences) and behaviors has often been portrayed in the literature as a mechanism for ensuring social stability and democracy, through which the attitudes between subsequent generations within a country are quite similar (Sapiro, 2004, Almond and Verba, 1963). Although there is anecdotal evidence of youngsters rebelling against their parents' value patterns, this is no means a general pattern (Hyman, 1959, Jennings and Niemi, 
1968, Niemi et al., 1978, Mannheim, 1952). In general, young people do tend to share the political preferences and the beliefs of their parents, and the correlation between the attitudes of parents and children is usually quite strong (Jennings and Niemi, 1968, Tedin, 1974).

There are at least two reasons to explore the intergenerational transmission of political participation using recent data. First, in the recent literature on political socialization, other socializing agents besides parents have received more attention (Stoker and Jennings, 1995, Niemi and Hepburn, 1995). Various authors have highlighted the importance of school experiences, the media, peer groups and other socialization experiences (Galston, 2001, Sapiro, 2004), which seems to imply that families are now considered less important political socialization agents. This article examines whether parents still have a significant influence on their children's level of intended political participation, and how they affect it.

Second, whereas many studies have explored the transmission of party identification, which was found to be one of the strongest transmission patterns (Dalton, 1980; Jennings, Stoker, \& Bowers, 2009; Westholm \& Niemi, 1992; Zuckerman, Dasović, \& Fitzgerald, 2007), only a few studies have explored the transmission of political participation from both parents to their children (Jennings \& Stoker, 2009). For a long time researchers perceived adolescents not as full citizens, but as 'citizens in the making' without political rights (Gordon, 2010). As a consequence, only a small body of literature addresses the intergenerational transmission of political participation (Amnå, 2012). Jennings et al. (2009), for instance, have explored the transmission of political engagement, but they measured it as political interest and political knowledge. As the respondents in this study were relatively young (e.g., 15), and thus political participation was less self-evident, we tried to overcome this difficulty by asking them about their intention to participate. 
This study provides new information on the transmission patterns of political participation intentions using an innovative dataset. Compared to other studies of intergenerational transmission, the dataset used in our analysis contains self-reported information on political participation and other relevant attitudes from more than 2,000 mother, father and child triads (however see Matthews et al., 2010, Jennings et al., 2009, Jennings and Niemi, 1968). Having information from both parents is important, as Acock and Bengston (1978) note: “A oneparent research design makes little sense, however, if the research question concerns parental influence.” Using the 2012 Belgian Parent-Child Socialization Study, we explore whether intergenerational transmission takes place, and which factors mediate this relationship.

\section{THEORETICAL FRAMEWORK}

The main questions in this article are whether (and how) the transmission of political participation occurs. Parents' political participation can either (1) directly influence the child's political participation intention or (2) be mediated by other factors (i.e., indirect influence) (Gordon, 2008, Quéniart, 2008, Matthews et al., 2010, Nesbit, 2012). Below, we briefly discuss the literature on direct and indirect transmission.

\section{Direct intergenerational transmission}

Intergenerational transmission is an application of the social learning theory (Bandura, 1986, Jennings et al., 2009). Children learn through observation and imitation: children observe when parents participate in politics, and are more likely to act similarly in the future. In this way, parents can effectively function as a role model (Mustillo et al., 2004). As mentioned above, little research has considered the direct parental socialization of political participation. Direct intergenerational transmission happens when children directly imitate their parents' political participation behavior, when they receive direct instruction on how to participate in politics and due to explicit parental expectations (Nesbit, 2012, Spellings et al., 2012). We have been able to identify only a few studies that investigate the intergenerational 
transmission of political participation. Jennings and Niemi (1981) found that there is a correlation of 0.16 for turnout and 0.27 for political participation between parents and children. Plutzer (2002) also uses Jennings and Niemi's data to demonstrate that children are more likely to vote as adults if they saw their parents vote when they were children. Similarly, it has been shown that if parents are civically involved (in school or other associations), their children are more likely to be politically active later in life (registering to vote, voting in elections, volunteering, being involved in a political campaign, being a member of a political organization) (McFarland and Thomas, 2006). Matthews et al. (2010) explore the transmission of civic activity and find that the effect of adult civic identity on child civic identity is around 0.3, controlling for a number of variables. Roker et al. (1999) also found, using qualitative interviews, that if a young person had a parent who was involved in some form of volunteering or campaigning then he or she was much more likely to participate in community activities. More recently, Coffé and Voorpostel (2011) explored the transmission of turnout and political participation among 18 to 25 year olds using the Swiss Household Panel. Standardized parameter estimates of the transmission of political participation are modest but significant, around 0.1-0.2.

Whereas the research on the intergenerational transmission of political participation is quite limited, more research has been conducted on the transmission of political attitudes, for instance on the transmission of political interest, knowledge, efficacy, trust, etc. This research suggests that there is substantial intergenerational transmission of political attitudes. Below, we briefly present some correlations. For political interest, Jennings et al. (2009) find unstandardized estimate effect sizes of 0.10-0.18 (similar to the effects reported in Coffé and Voorpostel (2011)). For political knowledge, the effects are slightly larger (e.g., unstandardized estimates of 0.42; Dalton (1980) reports correlations of 0.25-0.50), and these estimates remain quite stable between the 1960s and 1990s. Political efficacy also has a low 
level of transmission if one uses item correlations (0.14), but using structural equation modeling (and thus controlling for measurement error) this transmission increases to a correlation of 0.49 (Dalton, 1980). The transmission of political trust ranges between 0.05 and 0.30 (Dalton, 1980; Jennings et al., 2009). Thus overall, the literature shows that there is intergenerational transmission of political participation and political attitudes, but that this transmission is quite modest.

This literature leads us to the first hypothesis (direct transmission hypothesis): the parents' political participation is directly transmitted to the child's political participation intention.

\section{Indirect intergenerational transmission: mediating factors}

A literature review revealed three factors that traditionally have a strong influence on political participation intentions (Almond \& Verba, 1963; Rosenstone \& Hansen, 2003; Verba, Schlozman, \& Brady, 1995; Verba, Schlozman, \& Burns, 2005) and are thus more likely to mediate the transmission of political participation. In the literature, we find that cognitive skills might mediate the mechanism by which behavior is transmitted (Bandura, 1986), in the political science literature often operationalized as political discussion (Jennings et al., 2009) or political interest (Gabriel \& van Deth, 1995). Furthermore, it has been shown that socioeconomic status is one of the most influential predictors of political participation and is transmitted within families as well (Quintelier and Hooghe, 2013, Schlozman et al., 2012). Therefore, we will control for whether political discussion in the family, the child's political interest and the family's socio-economic status influence the transmission of political participation. By mediating, we mean that the direct effect of transmission can be explained by these three factors (i.e., that the parents' political participation influences the mediator, which in turn relates to the political participation intention of the children). In the analysis, adding the mediating factors should thus produce lower direct transmission levels, and suggest that transmission is a rather indirect process. 


\section{Political discussion in the family}

The social learning theory, as well as the attitude stability literature, argue that transmission is more successful in families if the topic (in our case, politics) is more important. Children in families with more discussion might be more easily mobilized and prone to engage in politics. This importance or high issue salience of politics within families has been operationalized as 'highly politicized families,' measured as the amount of political discussion in the family and the parents' level of political participation (Jennings et al., 2009, Dalton, 1980, Jennings and Niemi, 1968, Tedin, 1974, Flanagan, 2013). Lane (1959) found, using qualitative interviews, that in families in which politics is less salient, there is less need to discuss politics with parents or to challenge their ideas. Transmission in these families is thus lacking. Social capital increases access to human capital, according to Coleman (1988): as parents have more frequent contact with their children (i.e., spend more time with them and do more joint activities), children will have more access to their human capital. Although Coleman did not explicitly refer to politics, his theory can be used here as well: if parents do not interact with their children on politics, parents' political participation might be irrelevant for the children's political behavior, because social interaction provides the information required for effective transmission (Anderson, 2009). Research has indeed shown that more political discussion leads to more effective transmission. Several studies have shown that adolescents who discuss politics more often with their parents are more civically engaged (Kahne and Sporte, 2008, Verba et al., 1995, Diemer and Li, 2011). Jennings and Niemi (1968) found that although political conversation matters for transmission, it does not matter equally for all political attitudes.

\section{Political interest}

A second mediating factor for transmission is the child's level of political interest. As young politically interested people have more cognitive skills to model their behavior, they will be 
more likely to adapt their own behavior to that of their role models. Furthermore, these children will also be more attentive to their parents' (political) behavior (Bandura, 1977, Beck and Jennings, 1991). With regards to political behavior, political interest clearly is such a mediating mechanism. Dalton (1980) claims that the transfer from parents to children can be affected by political attitudes, the most important of which is political interest. Dalton (1980) found that the transmission of partisan agreement is higher among more interested children. Matthews et al. (2010) similarly found that the civic interest of the children mediates the effect of adult civic activity on youth civic identity. Similarly, it has been shown that if undergraduates report that their parents are more politically active, they are more likely to be politically interested, which in turn leads to higher political participation (Stockemer, 2012).

\section{Family socio-economic status}

Families not only transmit political participation directly; it also happens indirectly through the family's socio-economic status (Nesbit, 2012, Mustillo et al., 2004). As Dalton (1980) stressed, "parents and children normally share the same cultural, social and class milieu, providing additional resources of indirect parental socialization." Through this 'social milieu pathway' or 'status transmission model,' young people inherit their parents' social status as well as the accompanying levels of political attitudes (Dalton, 1982, Tedin, 1974) and political participation (McFarland and Thomas, 2006, Schlozman et al., 2012). Vollebergh et al. (2001), for instance, show that children inherit their parents' social status. Coffé and Voorpostel (2011) find that higher-educated mothers are more likely to transfer their higher levels of participation to their children. A higher socio-economic status leads to more political participation as well as a higher transmission of political participation. So, we should not only control for family socio-economic status, but also for the transmission of socio-economic status from parents to children. Socio-economic status is expected to reduce the level of direct intergenerational transmission of political behavior. Schlozman et al. (2012), for instance, find 
that political participation is mainly indirectly transmitted through socio-economic status. Other research has shown that controlling for parent education and family income reduces the effect of parental political knowledge on the child's political knowledge (Jennings et al., 2009).

This leads to the second hypothesis (indirect transmission hypothesis): the intergenerational transmission of political participation is (partly) mediated by: (a) political discussion in the family, (b) political interest of children and (c) the socio-economic status of the family. Although other factors possibly mediate this relationship, the available literature suggests that these factors are the most decisive, both for intergenerational transmission and political participation.

\section{METHOD}

Our analysis employs structural equation modeling. This method has been previously used by several authors (Dalton, 1980, Vollebergh et al., 2001), who argued that it is necessary for studying intergenerational transmission because the concepts involve an underlying (e.g., latent) factor, and the items themselves suffer from measurement error. Using this type of modeling leads to a higher correspondence between parents and children, which is also a more reliable presentation of reality (Dalton, 1980, Acock and Bengtson, 1978). In the analysis, we will test the following model using structural equation modeling (Figure 1).

\section{Figure 1}

Although we use unidirectional arrows from parents to children (except between parents' political participation and socio-economic status, where we estimate a correlation), we are aware that children might also affect parents' political behavior and attitudes, although this reverse socialization is less likely. Similarly, political discussion at home might simultaneously influence parental political participation and the child's intended political 
participation. Unfortunately, a single wave does not allow us to disentangle these processes, and research has demonstrated that parents tend to influence their children more strongly than the other way around (Vollebergh et al., 2001).

The data are from the 2012 Parent-Youth Socialization Study (Hooghe et al., 2012), a representative survey of 3,426 15 year olds $\left(9^{\text {th }}\right.$ grade) administered in school in the Dutchspeaking part of Belgium. The schools $(n=61)$ were selected by a stratified sample based on province and educational track. Students were surveyed on their social and political values, as well as their socio-economic status and family composition. The data are representative for gender and educational track. The students were given a survey on similar topics for both their father and mother. The survey was filled in by the parents at home and sent back to the university conducting the research. Parents who did not send the survey back spontaneously were contacted twice by phone or mail. Complete information is available for 61 percent $(n=2,085)$ of the students. For these children, two (mostly biological) parents both filled in the survey. ${ }^{\mathrm{i}}$

We use the children's intention to participate in politics as the dependent variable, because young people rarely participate actively in politics when they are under 18 . Therefore, most studies of young people use this intention question (Benton et al., 2009; Torney-Purta, 2002), which has been shown to be a reasonably valid indicator (e.g., for voting) (Achen \& Blais, 2010), yet more research is needed to determine the size of the relationship between intentions and actions and whether both can be explained through the same indicators (Persson, 2012). Furthermore, using the actual political behavior of the child could artificially inflate our correlation, as we do not know whether the child participated in a protest march because (s)he wanted to or because their parents forced them to. By using the intention to participate, we hope to measure only the child's intention to be voluntarily involved in politics in the future. Young people were asked in which of five political activities they intended to participate in 
the near future (1=never; $2=$ maybe; $3=$ =ertainly): boycott products for a political reason, participate in a protest, become a member of a political or social organization, wear a t-shirt or sticker to express their opinion, and collect signatures for a petition. These items prove to be a unidimensional scale (Chi2: 41.309(5df)***; Comparative Fit Index (CFI) 0.987; Root Mean Square Error of Approximation (RMSEA) 0.046; factor loadings of boycott and protest can be constrained to be equal (Chi2: 3.701(1df)ns)). The descriptives of each item are presented in Table 1. Voting was not included, given that voting is compulsory in Belgium from the age of 18 onwards and this estimate might be biased in Belgium and limit the possibility to compare the results internationally.

We use the parents' political participation as the independent variable since we know that parents have participated in these activities, and children might have seen this engagement (and might even have participated themselves). Parental (non-institutionalized) political participation was measured by asking mothers and fathers whether they had participated in a list of political activities in the last year. Both mothers and fathers could indicate whether they had 'never,' 'sometimes' or 'often' (1) boycotted certain products for political reasons, (2) participated in a protest march or (3) posted messages on discussion or message boards online (all factor loadings can be constrained within each factor to be equal (Chi²: 5.729(4df)ns)). Both parents' non-institutionalized political participation proved to be a separate latent factor.

We also measured parents' electoral political participation. We asked both whether they had helped a candidate during the last election and whether they had been a candidate at the last election (e.g., electoral/institutionalized political participation). These four items (two for each parent) are a single dimension. Thus parental political participation is most appropriately modeled as a second-order factor model (see Figure 1): a latent factor of political participation consisting of three latent factors (non-institutionalized political participation mother, political participation father and electoral participation parents) (Chi²: 159.336(32df)***; CFI 0.925; 
RMSEA 0.041; second-order factor loadings can be constrained to be equal (Chi²:

$1.458(1 \mathrm{df}) \mathrm{ns})$.$) .$

Political discussion within the family was measured using the question "How often have you talked about politics with your parents?" (both mother and father): never, once or twice, several times or often. Both items were highly correlated $\left(0.678^{* * *}\right)$, and thus included as a latent factor. Political interest of the child was measured using the question "How interested are you in societal issues and politics?" The answers varied from 'not interested' to 'a little interested,' 'interested' and 'very interested.'

Socio-economic status of the family was measured using the educational track of the child (general, technical/artistic or professional education), the number of books at home using a 7point scale ranging from 'none' to 'more than 500,' and the highest obtained degree of both parents (lower education, lower secondary education, higher secondary education, higher nonuniversity education, university degree). Analysis shows that this measurement for socioeconomic status is unidimensional $\left(\mathrm{Chi}^{2}\right.$ : $9.549(2 \mathrm{df})^{* *}$; CFI: 0.998; RMSEA: 0.033; factor loadings of highest obtained degree of mother and father can be constrained to be equal (Chi²: $1.038(1 \mathrm{df}) \mathrm{ns}))$. As socio-economic status is used as a mediating variable, we cannot also use it as a control variable. Nevertheless, we control for the gender of the child ( $46 \%$ female) and whether the child is born in Belgium (91\%). Gender differences in intergenerational transmission (self-cite) and the marital status of the parents did not influence the transmission of political participation.

Table 1. 


\section{RESULTS}

We built the intergenerational transmission model stepwise. First we included only the direct effect, and in the following models we added one mediating factor at a time, followed by a full model including all mediating factors.

\section{Direct transmission model}

First we explored the direct transmission of political participation controlling for gender and nationality, excluding mediating factors. We find that there is indeed a significant transmission of parental political participation to the child's intention to participate (i.e., children with politically active parents are more likely to assert that they will be politically active in the future). There is a standardized effect of $0.223 * * *(\mathrm{~B}: 0.310(0.073)$ ) of parents on child's political participation intention, which is in line with analyses of other datasets (Jennings and Niemi, 1981, Coffé and Voorpostel, 2011) (See Figure 1). The question is then how this mechanism can be explained: is it the direct observation of the children (Bandura, 1977) or indirect transmission reinforced by political discussion within the family (Kahne and Sporte, 2008), transmission of family socio-economic status (Schlozman et al., 2012) or the child's political interest (Beck and Jennings, 1991)? We explore these possibilities below.

\section{Figure 1.}

\section{Indirect transmission model}

The first intermediating mechanism is political discussion, which teaches children that political participation is important to their parents. Children in families with more political discussion are more likely to be politically engaged (Kahne and Sporte, 2008, Verba et al., 1995). Politically active parents are more likely to discuss politics with their children ( $\mathrm{p}<$ 0.001), and through this political discussion, children are more likely to become more politically active. This mechanism reduces the direct effect of political participation, though 
not completely: controlling for political discussion in the family, there is still some direct transmission of political participation habits from parents to children (see Table 2).

The second mediating factor is political interest. Having a politically active parent increases children's attentiveness towards everything political and stimulates their political interest. It is also generally accepted that political interest leads to more political participation (Verba et al., 1995, Neundorf et al., 2013). The process of political interest (rather than the observation of parental activism) seems to increase political participation: children with politically active parents are more likely to be interested in politics, and this interest increases their likelihood to participate in the future. This finding is similar to Stockemer's (2012), with the exception that he did not fit a direct path between parents' perceived political participation and young adults' political participation intention - a path that is clearly significant here.

The third mediating factor is socio-economic status. Verba et al. (2012) suggest that socioeconomic status (with its accompanying levels of political participation)—not political participation behavior - is transmitted from parent to child. Table 2 shows that this indeed is the case: socio-economic status mediates the direct transmission of parental political participation on a child's intended political participation. On the one hand, parental political participation is linked with the family's socio-economic status, a finding that is universal in political participation research (Marien et al., 2010, Verba et al., 1995). On the other hand, children in families with a higher socio-economic status are more likely to participate, though this effect does not completely mediate the direct effect of political participation. When we compare all direct and indirect effects, we find that about half of the total effect can be explained by the indirect effect, which demonstrates that the mediating factors are clearly important.

Table 2. 
Finally, we combined all mediating factors into a single model to explore whether political participation is directly or indirectly transmitted. The latter seems to be the case: if we control for political interest, political discussion and socio-economic status of the family, we find no significant direct effect of parental political involvement on a child's intention to participate in politics: this effect is completely mediated. This is also reflected in the calculation of the indirect and total effect: the indirect effect is as large as the total effect (I: $0.440(0.076)^{* * *}$; T: 0.451(0.099)***). Although parents can create an environment that fosters political participation, children do not develop the intention to participate by observation directly (Bandura, 1977). Parents do play an important role in creating this environment: through their higher socio-economic status, more political discussion in the family and arousing children's interest, they create a more politicized family environment (Jennings et al., 2009), which increases the odds of intended political participation among children. We also controlled for whether divorce has a significant effect on political participation in the final model; this effect proved to be not significant. Furthermore, the transmission levels do not differ significantly between traditional and divorced parents.

\section{Figure 2.}

\section{DISCUSSION}

The results of this study support the thesis that political participation is not directly transmitted from parent to child, but rather is transmitted indirectly through a more politicized family environment (Hess and Torney, 1967, Jennings et al., 2009). A more politicized family environment is measured here as the level of political discussion, the influence on the political interest of the child and the socio-economic status of the family. The analysis revealed that all three factors are linked with both the parents' political participation and the child's intended political participation. A higher level of political activity among parents is associated with a higher family socio-economic status (and vice versa), more political discussion in the family 
and a higher political interest of the child. Thus there is more support for the status transmission theory, which argues that the parents' resources reduce the direct effects of socialization, or even render these processes irrelevant.

In general, the transmission levels are quite low. How can these low levels of direct transmission between parents and children be explained? Children may simply be too young for their political attitudes to be influenced by their parents. Jennings and Niemi's (1981, pp. 76-113; Jennings \& Stoker, 2009) study, however, shows that 18- and 25-year-old adults demonstrate a similar correspondence with their parents with regard to political attitudes. Dotti Sani and Quaranta (2013) also find evidence that parents' influence increases as children are in their 20s. It might be the case that the 15 year olds in our study will become more similar to their parents in five to ten years, but the overall evidence makes this less likely. Furthermore, it might be that children do not really know what their parents do. We expect them to notice that their parents are candidates in elections and whether they buy environmental products, however they might not know whether their parents go to political meetings or voice their political opinions online. Although we know the parents' behavior and the children's intention, we do not know the children's perception of their parents' political activity. The children may perceive their parents as being politically active where they are not - even the idea itself might reinforce their engagement - or the other way around: children might not be aware that their parents are politically active and therefore not be influenced by their behavior (Tedin, 1974, Jennings and Niemi, 1968, Padilla-Walker, 2007). In Bandura's words, this process might be mediated by cognitive skills: only politically interested children can accurately perceive whether their parents are politically active. And this is exactly what we have observed here. Political discussion might work in the same manner: it teaches children what their parents do, which allows them to model their behavior accordingly. Future research can examine attitudes that might affect political participation (Dassonneville, 2012, 
Fraile, 2013). Transmission seems to be a quite equal process that works similarly for all people. Overall, the theoretical literature might overestimate the transmission of attitudes and behavior, which was suggested 50 years ago: "the effectiveness of the family in transmitting attitudes have been overestimated in previous research" (Hess and Torney, 1967); the authors added that most socialization happens indirectly, which is the case here as well.

Of course, this article is part of a larger literature on intergenerational transmission, political socialization, genetic research, and the issue of whether we measure actual or perceived attitudes. First, throughout this article, we have argued that transmission is unidirectional: from parents to children. Although this is the most plausible option, children may also affect their parents' attitudes (Dalton, 1980, McDevitt and Chaffee, 2002). Vollebergh et al. (2001) have tested this reciprocal influence and found that although children have an effect on parents, parents' effect on children is significantly stronger, except in the case of ethnocentrism. Second, although we focus on generational transmission here, we are aware that a large part of the transmission is genetic in nature. In recent years, much research has been done on the effect of genetics in determining political attitudes and behavior using mono- and dizygotic twins. The findings in this article are in line with this stream of research, although it has yet to be established how much of the transfer is determined by genes rather than socialization. Because we do not have access to data for monozygotic and dizygotic twins, we cannot determine the percentage of transmission through genes (Eaves and Hatemi, 2008, Funk et al., 2010). Third, the data that were gathered for this project are limited to the Belgian context. Further research should explore whether they are generalizable elsewhere. The limited evidence, however, points to quite universal patterns, at least in Western countries (Dotti Sani \& Quaranta, 2013; Jennings \& Stoker, 2009; Voorpostel \& Coffé, 2012). Fourth, we have studied the effect of actual parental participation on the child's intented political participation. Yet, more research is needed whether intention the participate translates into 
actual behavior later in life. Furthermore, Sances (2013) has shown that divorce is a proxy for “an unobservable trait that jointly influences the decision to socialize one's children into politics and the decision to separate" which suggests that other causal mechanisms might be at work here. Yet this article might be a step towards exploring the causal effects, as suggested by Sances (2013), since the effect is rendered non-significant when several variables are controlled for. In these analyses, whether or not children were living with both biological parents did not influence our findings, but further research could explore this issue in more depth.

(WORD COUNT: 7,387, 12 MAY 2014) 


\section{REFERENCES}

Achen, C. H., \& Blais, A. (2010). Intention to Vote, Reported Vote, and Validated Vote. Paper presented at the APSA 2010 Annual Meeting.

Acock, A. C. and Bengtson, V. L. (1978) Relative Influence of Mothers and Fathers Covariance Analysis of Political and Religious Socialization. Journal of Marriage and the Family 40 (3): 519-530.

Almond, G. A. and Verba, S. (1963) The Civic Culture: political attitudes and democracy in five nations. Princeton: Princeton University Press.

Amnå, E. (2012) How is civic engagement developed over time? Emerging answers from a multidisciplinary field. Journal of Adolescence 35 (3): 611-627.

Anderson, M. R. (2009) Beyond Membership: A Sense of Community and Political Behavior. Political Behavior 31 (4): 603-627.

Bandura, A. (1977) Social Learning Theory. Englewood Cliffs, NJ: Prentice Hall.

Bandura, A. (1986) Social foundations of thoughts and action: A social cognitive theory. Englewood Cliffs: Prentice Hall.

Beck, P. A. and Jennings, M. K. (1991) Family Traditions, Political Periods, and the Development of Partisan Orientations. The Journal of Politics 53 (03): 742-763.

Benton, T., Cleaver, E., Featherstone, G., Kerr, D., Lopes, J. and Whitby, K. (2009) Citizenship Education Longitudinal Study (CELS): Sixth Annual Report Young People's Civic Participation In and Beyond School: Attitudes, Intentions and Bronfenbrenner, U. (1979) The ecology of human development: experiments by nature and design. Cambridge: Harvard University Press.

Coffé, H. and Voorpostel, M. (2011) Intergenerational Transmission of Political Participation. The Importance of Parental Level of Education. 
Coleman, J. S. (1988) Social Capital in the Creation of Human Capital. American Journal of Sociology 94 95-120.

Dalton, R. J. (1980) Reassessing Parental Socialization: Indicator Unreliability Versus Generational Transfer. American Political Science Review 74 (2): 421-431.

Dalton, R. J. (1982) The Pathways of Parental Socialization. American Politics Quarterly 10 (2): 139-157.

Dassonneville, R. (2012) Electoral volatility, political sophistication, trust and efficacy: A study on changes in voter preferences during the Belgian regional elections of 2009. Acta Politica 47 (1): 18-41.

Davies, J. C. (1965) The Family's Role in Political Socialization. Annals of the American Academy of Political and Social Science 361 10-19.

Dawson, R. E. and Prewitt, K. S. (1969) Political socialization. An Analytic Study. Boston: Little Brown.

Diemer, M. A. and Li, C.-H. (2011) Critical Consciousness Development and Political Participation Among Marginalized Youth. Child Development 82 (6): 1815-1833.

Dotti Sani, G. M., \& Quaranta, M. (2013). Chips off the old blocks? The intergenerational transmission of political participation in Italy. unpublished manuscript.

Eaves, L. J. and Hatemi, P. K. (2008) Transmission of Attitudes Toward Abortion and Gay Rights: Effects of Genes, Social Learning and Mate Selection. Behavior Genetics 38 $247-256$.

Flanagan, C. A. (2013) Teenage Citizens. The Political Theories of the Young. Harvard: Harvard University Press.

Fraile, M. (2013) Do information-rich contexts reduce knowledge inequalities? The contextual determinants of political knowledge in Europe. Acta Politica 48 (2): 119143. 
Funk, C. L., Smith, K. B., Alford, J. R., Hibbing, M. V., Hatemi, P. K. and Hibbing, J. R. (2010) Toward a Modern View of Political Man: Genetic and Environmental Sources of Political Orientations and Participation.

Gabriel, O. W., \& van Deth, J. W. (1995). Political interest. In J. W. van Deth \& E.

Scarbrough (Eds.), The Impact of Values (pp. 390-411). Oxford: Oxford University Press.

Galston, W. A. (2001) Political Knowledge, Political Engagement, and Civic Education. Annual Review Political Science 4 217-234.

Gordon, H. R. (2008) Gendered Paths to Teenage Political Participation: Parental Power, Civic Mobility, and Youth Activism. Gender \& Society 22 (1): 31-55.

Gordon, H. R. (2010) We Fight To Win: Inequality and the Politics of Youth Activism. New Brunswick: Rutgers University Press.

Hess, R. D. and Torney, J. V. (1967) The Development of Political Attitudes in Children. Chicago: Aldine.

Hooghe, M., Quintelier, E., Verhaegen, S., Boonen, J. and Meeusen, C. (2012) Parent-Child Socialization Study 2012. Technical Report. Leuven: KU Leuven.

Hooper, D., Coughlan, J. and Mullen, M. R. (2008) Structural Equation Modelling: Guidelines for Determining Model Fit. Electronic Journal of Business Research Methods 6 (1): 53-60.

Hyman, H. H. (1959) Political Socialization. Glencoe: Free Press.

Jennings, M. K. and Niemi, R. G. (1968) The transmission of political values from parent to child. American Political Science Review 62 (1): 169-184.

Jennings, M. K. and Niemi, R. G. (1981) Generations and politics: a panel study of young adults and their parents. Princeton: Princeton University Press. 
Jennings, M. K., \& Stoker, L. (2009). Continuities in Political Participation across Multiple Generations. Paper presented at the 2009 Midwest Political Science Association Convention, Chicago.

Jennings, M. K., Stoker, L. and Bowers, J. (2009) Politics across Generations: Family Transmission Reexamined. Journal of Politics 71 (3): 782-799.

Kahne, J. E. and Sporte, S. E. (2008) Developing citizens: The impact of civic learning opportunities on students' commitment to civic participation. American Educational Research Journal 45 (3): 738-766.

Lane, R. E. (1959) Fathers and sons: foundations of political beliefs. American Sociological Review 24 (4): 502-511.

Langton, K. P. (1969) Political socialization. New York: Oxford University Press.

Lochner, L. (2008) Intergenerational Transmission. In: Blume, L. E. and Durlauf, S. N. (eds.) New Palgrave Dictionary of Economics, 2nd Edition. London: Palgrave, pp.

Mannheim, K. (1952) The problem of generations. In: Kecskemeti, P. (eds.) Essays on the Sociology of Knowledge by Karl Mannheim. New York: Routlegde \& Kegan Paul, pp. 276-322.

Marien, S., Hooghe, M. and Quintelier, E. (2010) Inequalities in Non-institutionalised Forms of Political Participation: A Multi-level Analysis of 25 countries. Political Studies 58 (1): 187-213.

Matthews, T. L., Hempel, L. M. and Howell, F. M. (2010) Gender and the Transmission of Civic Engagement: Assessing the Influences on Youth Civic Activity. Sociological Inquiry 80 (3): 448-474.

McDevitt, M. and Chaffee, S. (2002) From Top-Down to Trickle-up Influence: Revisiting Assumptions About the Family in Political Socialization. Political Communication 19 (3): 281-301. 
McFarland, D. A. and Thomas, R. J. (2006) Bowling young: How youth voluntary associations influence adult political participation. American Sociological Review 71 (3): 401-425.

Mustillo, S., Wilson, J. and Lynch, S. M. (2004) Legacy Volunteering: A Test of Two Theories of Intergenerational Transmission. Journal of Marriage and Family 66 (2): $530-541$.

Muthén, L. K. and Muthén, B. O. (2010) Mplus User's Guide. Sixth Edition. Los Angeles, CA: Muthén \& Muthén.

Nesbit, R. (2012) The Influence of Family and Household Members on Individual Volunteer Choices. Nonprofit and voluntary sector quarterly.

Neundorf, A., Smets, K. and Garcia-Albacete, G. M. (2013) Homemade citizens: The development of political interest during adolescence and young adulthood. Acta Politica 48 (1): 92-116.

Niemi, R. G. and Hepburn, M. A. (1995) The rebirth of political socialization. Perspectives on Political Science 24 (1): 7-16.

Niemi, R. G., Ross, D. R. and Alexander, J. (1978) The Similarity of Political Values of Parents and College-Age Youths. Public Opinion Quarterly 42 (4): 503-520.

Padilla-Walker, L. M. (2007) Characteristics of Mother-Child Interactions Related to Adolescents' Positive Values and Behaviors. Journal of Marriage and Family 69 (3): 675-686.

Persson, M. (2012). Does Type of Education Affect Political Participation? Results from a Panel Survey of Swedish Adolescents. Scandinavian Political Studies, 35(3), 198221.

Plutzer, E. (2002) Becoming a Habitual Voter: Inertia, Resources, and Growth in Young Adulthood. American Political Science Review 96 (1): 41-56. 
Quéniart, A. (2008) The Form and Meaning of Young People's Involvement in Community and Political Work. Youth \& Society 40 (2): 203-233.

Quintelier, E. and Hooghe, M. (2013) The impact of socio-economic status on political participation. In: Demetriou, K. N. (eds.) Democracy in Transition. Political Participation in the European Union. London: Springer, pp. 273-289.

Roker, D., Player, K. and Coleman, J. (1999) Young peoples voluntary and campaigning activities as sources of political education. Oxford Review of Education 25 (1/2): 185198.

Rosenstone, S. J., \& Hansen, J. M. (2003). Mobilization, participation, and democracy in America. New York: Longman.

Sances, M. W. (2013) Disenfranchisement Through Divorce? Estimating the Effect of Parental Absence on Voter Turnout. Political Behavior 35 (1): 199-213.

Sapiro, V. (2004) Not your parents' political socialization: Introduction for a new generation. Annual Review of Political Science 7 (1): 1-23.

Schlozman, K. L., Verba, S. and Brady, H. E. (2012) The Unheavenly Chorus. Unequal Political Voice and the Broken Promise of American Democracy. Princeton: Princeton University Press.

Spellings, C. R., Barber, B. K. and Olsen, J. A. (2012) Political Activism of Palestinian Youth: Exploring Individual, Parental, and Ecological Factors. Journal of Marriage and Family 74 (5): 1084-1100.

Stockemer, D. (2012) Students' political engagement: a comprehensive study of University of Ottawa undergraduate students. Journal of Youth Studies 15 (8): 1028-1047.

Stoker, L. and Jennings, M. K. (1995) Life-Cycle Transitions and Political Participation: the case of marriage. American Political Science Review 89 421-434. 
Tedin, K. L. (1974) The influence of Parents on the Political Attitudes of Adolescents. American Political Science Review 68 (4): 1579-1592.

Torney-Purta, J. (2002) Patterns in the Civic Knowledge, Engagement, and Attitudes of European Adolescents: The IEA Civic Education Study. European Journal of Education 37 (2): 129-141.

Verba, S., Schlozman, K. L. and Brady, H. E. (1995) Voice and equality: civic voluntarism in American Politics. Cambridge: Harvard University Press.

Verba, S., Schlozman, K. L., \& Burns, N. (2005). Family Ties. Understanding the Intergenerational Transmission of Political Participation. In A. S. Zuckerman (Ed.), The social logic of politics. Personal networks as contexts for political behavior. Philadelphia: Temple University.

Vollebergh, W. A. M., Iedema, J. and Raaijmakers, Q. A. W. (2001) Intergenerational Transmission and the Formation of Cultural Orientations in Adolescence and Young Adulthood. Journal of Marriage and Family 63 (4): 1185-1198.

Westholm, A. and Niemi, R. G. (1992) Political Institutions and Political Socialization: A Cross-National Study. Comparative Politics 25 (1): 25-41.

Zuckerman, A. S., Dasović, J., \& Fitzgerald, J. (2007). Partisan Families. The social logic of bounded partisanship in Germany and Britain. Cambridge: Cambridge University Press. 
Table 1. Descriptives

\begin{tabular}{|c|c|c|c|c|c|}
\hline & Mean & Std. Dev. & Min. & Max. & Missing \\
\hline \multicolumn{6}{|l|}{ Intended political participation } \\
\hline Boycott products & 1.72 & 0.69 & 1 & 3 & 22 \\
\hline Protest march & 1.59 & 0.63 & 1 & 3 & 5 \\
\hline Party member & 1.39 & 0.55 & 1 & 3 & 8 \\
\hline Wear a t-shirt or sticker & 1.55 & 0.64 & 1 & 3 & 7 \\
\hline Petitions & 1.63 & 0.62 & 1 & 3 & 14 \\
\hline \multicolumn{6}{|l|}{ Political participation mother } \\
\hline Boycott products & 1.51 & 0.62 & 1 & 3 & 52 \\
\hline Protest march & 1.07 & 0.26 & 1 & 3 & 56 \\
\hline Post online messages & 1.07 & 0.29 & 1 & 3 & 44 \\
\hline Help a candidate & 1.09 & 0.32 & 1 & 3 & 52 \\
\hline Be a candidate & 1.03 & 0.19 & 1 & 3 & 56 \\
\hline \multicolumn{6}{|l|}{ Political participation father } \\
\hline Boycott products & 1.39 & 0.59 & 1 & 3 & 126 \\
\hline Protest march & 1.10 & 0.32 & 1 & 3 & 130 \\
\hline Post online messages & 1.14 & 0.40 & 1 & 3 & 117 \\
\hline Help a candidate & 1.13 & 0.41 & 1 & 3 & 139 \\
\hline Be a candidate & 1.04 & 0.23 & 1 & 3 & 135 \\
\hline \multicolumn{6}{|l|}{ Mediating: Political discussion } \\
\hline With mother & 1.96 & 0.82 & 1 & 4 & 28 \\
\hline With father & 2.12 & 0.89 & 1 & 4 & 81 \\
\hline \multicolumn{6}{|l|}{ Mediating: Socio-economic } \\
\hline Educational track & 2.24 & 0.76 & 1 & 3 & 0 \\
\hline Number of books at home & 3.49 & 1.55 & 1 & 7 & 9 \\
\hline Degree mother & 3.46 & 0.96 & 1 & 5 & 50 \\
\hline Degree father & 3.38 & 1.07 & 1 & 5 & 124 \\
\hline \multicolumn{6}{|l|}{ Mediating: Political interest } \\
\hline Political interest & 1.99 & 0.75 & 1 & 4 & 5 \\
\hline \multicolumn{6}{|l|}{ Control variables } \\
\hline Girl & 0.46 & 0.49 & 0 & 1 & 1 \\
\hline Born in Belgium & 0.91 & 0.28 & 0 & 1 & 0 \\
\hline
\end{tabular}

Note: Missing cases for parents are mostly due to the fact that the parent did not return the survey, whereas the partner did send the survey back. Fathers have more missing cases than mothers because fathers were slightly less likely to respond. 
Table 2. Separate mediating factors of political participation transmission.

\begin{tabular}{|c|c|c|c|}
\hline Intermediating variable: & $\begin{array}{l}\text { Political } \\
\text { discussion }\end{array}$ & Political interest & $\begin{array}{c}\text { Socio-economic } \\
\text { status }\end{array}$ \\
\hline Direct transmission & $0.159(0.063)^{*}$ & $0.183(0.060)^{* *}$ & $0.178(0.068)^{* *}$ \\
\hline Political participation parent -> & 0.122 & 0.142 & 0.133 \\
\hline \multicolumn{4}{|l|}{ Intended participation child } \\
\hline Indirect transmission & $0.501(0.091)^{* * *}$ & $0.0412(0.092) * * *$ & $0.106(0.016)^{* * * \circ}$ \\
\hline Political participation parent -> & 0.299 & 0.223 & 0.383 \\
\hline \multicolumn{4}{|l|}{ Intermediary variable } \\
\hline Intermediary variable -> & $0.290(0.024)^{* * *}$ & $0.278(0.018)^{* * *}$ & $0.399(0.045)^{* * *}$ \\
\hline Intended participation child & 0.372 & 0.403 & 0.288 \\
\hline \multirow[t]{2}{*}{ Indirect effect } & $0.145(0.027)^{* * *}$ & $0.116(0.024) * * *$ & $0.146(0.027)^{* * *}$ \\
\hline & 0.111 & 0.090 & 0.110 \\
\hline \multirow[t]{2}{*}{ Total effect } & $0.305(0.071)^{* * *}$ & $0.298(0.069)^{* * *}$ & $0.325(0.074)^{* * *}$ \\
\hline & 0.233 & 0.231 & 0.243 \\
\hline \multicolumn{4}{|l|}{ Model fit } \\
\hline $\operatorname{Chi}^{2}(\mathrm{df})$ & $586.405(152)^{* * *}$ & $574.379(36)^{* * *}$ & $1103.829(190)^{* * *}$ \\
\hline RMSEA & 0.029 & 0.031 & 0.037 \\
\hline CFI & 0.965 & 0.917 & 0.901 \\
\hline
\end{tabular}


${ }^{\circ}$ we did not estimate an effect here, but a correlation (except to calculate the indirect effect).

Entries are unstandardized coefficients, standard errors and significances, standardized errors.

Indirect and total effect were computed using Mplus procedures (Muthén and Muthén, 2010). 
Figure 1. Direct transmission model

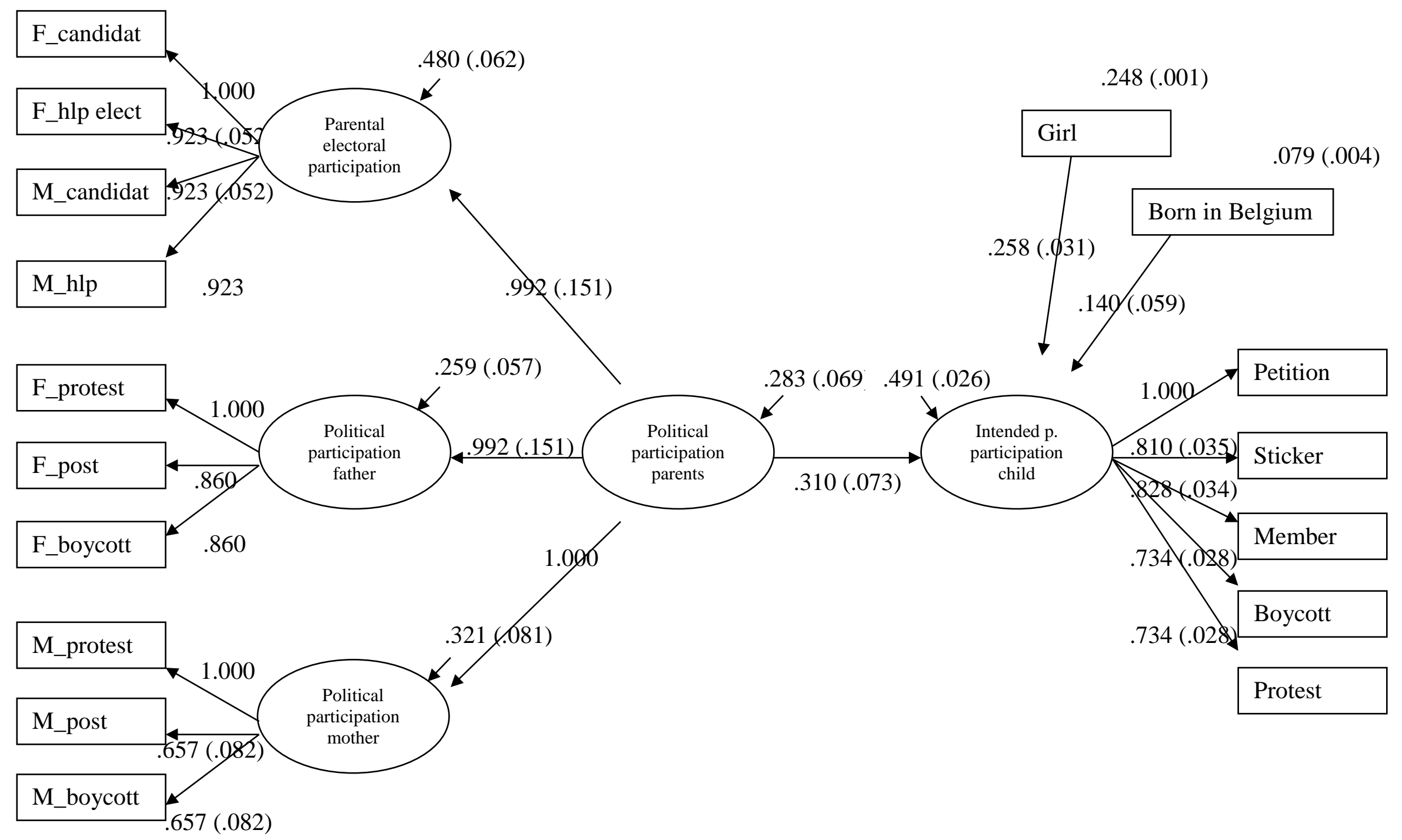


Model fit: Chi²: 473.804(421df)***; CFI: 0.922; RMSEA: 0.029). All parameters are significant at the .05 level. Entries are unstandardized coefficients, standard errors. 
Figure 2. Structural indirect transmission model (all mediating factors).

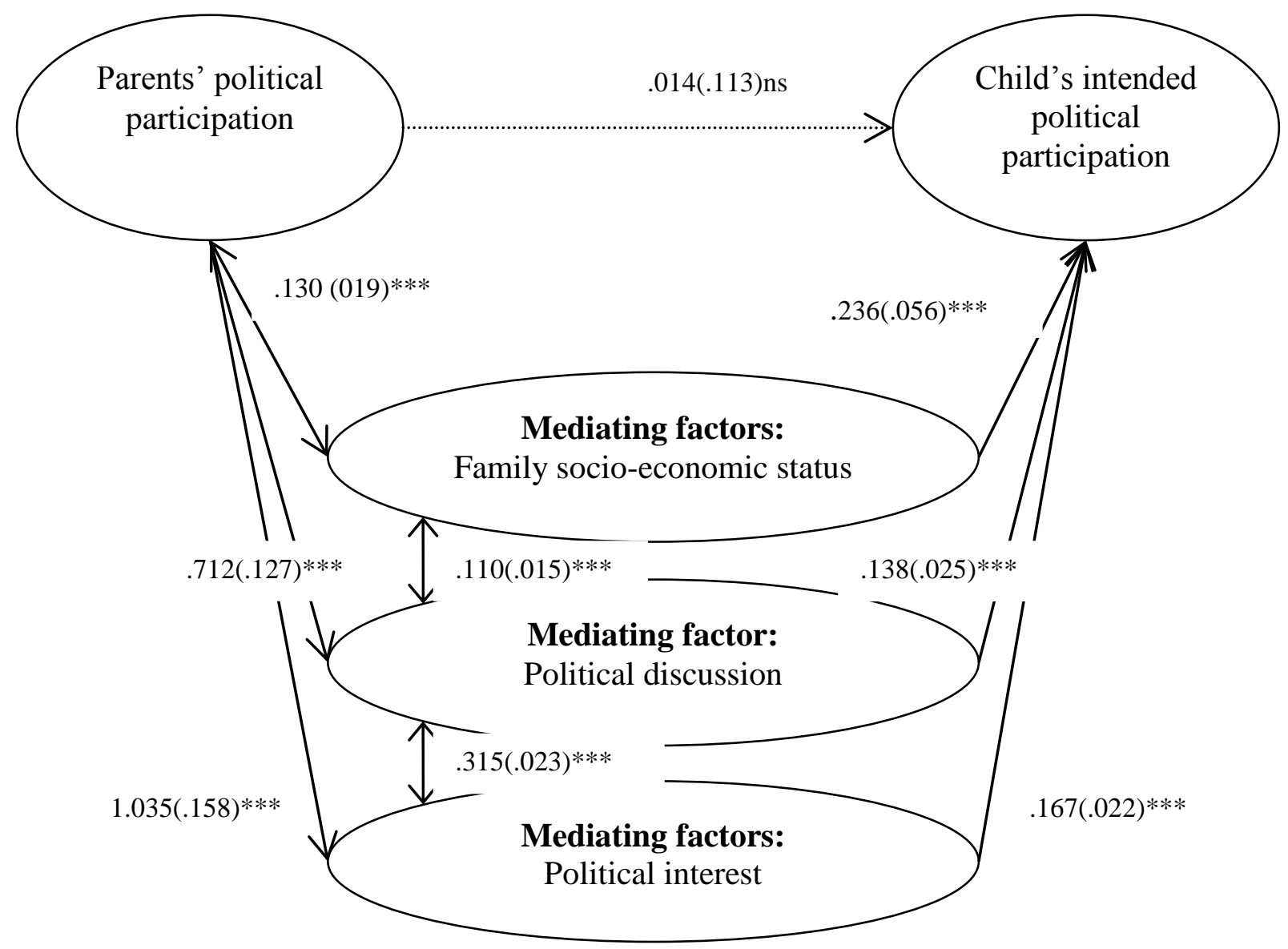

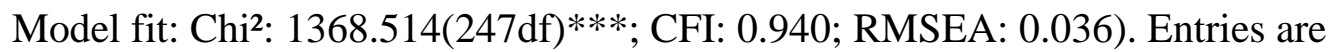
unstandardized coefficients, standard coefficients and significances (controlled for gender and nationality, latent factors are not presented).

\footnotetext{
${ }^{\mathrm{i}}$ It was also tested whether these models held for mothers and fathers separately, and this was actually the case: in these models, the results were quasi-identical
} 